\author{
International Journal of Law, Government and \\ Communication (IJLGC) \\ Journal Website: http://ijlgc.com/ \\ eISSN: 0128-1763
}

\title{
ROLES OF NEW MEDIA IN INDIA POLITICAL LANDSCAPE
}

\author{
Nurul Hidayah Hamid ${ }^{1}$, Awan Ismail ${ }^{2}$
}

$1 \quad$ School of Multimedia Technology and Communication (SMMTC), Universiti Utara Malaysia

Email: nurulhidayahhamid89@gmail.com

2 Senior Lecturer, Department of Multimedia Technology, School of Multimedia Technology and Communication (SMMTC), Universiti Utara Malaysia

Email: awan@uum.edu.my

Article Info:
Article history:
Received date: 10.09 .2019
Revised date: 15.09 .2019
Accepted date: 25.02 .2020
Published date: 10.03 .2020
To cite this document:
Hamid, N. H., \& Ismail. A. (2020).
Roles of New Media in India Political
Landscape. International Journal of
Law, Government and
Communication, 5 (18),26-42.

DOI: $10.35631 /$ IJLGC.518004.

\begin{abstract}
:
Today, new media especially social media became an important tool in human life from providing information, communication; discuss an issue to mobilize people. People can do whatever they want just by using social media every time for 24 hours and everywhere regardless of time or place. Moreover, new media either Facebook, Twitter or Youtube use by everyone including politicians these days to share their agenda, besides other methods. In India, the use of new media mainly Twitter seen play an important in Delhi General Election 2014. For example, most of the election participant such as Narendra Modi or and their parties, Bharatiya Janata Party (BPJ) seen using new media extensively in their online campaign to attract the voter. Thus, the purpose of this research is to understand the roles of new media on politic in India and how politician uses Facebook, Twitter or Youtube in their online campaign and spread out agenda. For this purpose, an in-depth interview (qualitative) was used to get the findings on the impact of new media in politics. There is few media organization staff and former worker partook in an in-depth interview. In the end, this study found that new media, of course, can affect people especially when it is being used frequently.
\end{abstract}

Keywords:

India, New Media, Social Media, Politician, Online Campaign, Voters

\section{Introduction}

According to Situmorang (2012), the emergence of internet links to new media that started with email and website only before arises the social media, blogs and so. What is new media? New media is defined as a term that shows the rising digital, computer or network information technology and communication at the end 20 century such as the internet, computer, 
multimedia and computer games (Putri, Prananingrum, \& Safirti, 2018). Nicoleta (2008) says that there are a few types of new media such as podcast and blog. Meanwhile, according to Friedman and Friedman (2008) also include social media (Facebook), social bookmarking (del.icio.us), Wikis (Wikipedia.com), video clips (YouTube) and so on.

Kaplan and Haenlein (2010) elaborated that social media is a platform that allows persons to talk issue, give an opinion and share daily life with others. Moreover, those social media giving chance for a user to interact with people, besides provide information regarding any issues. For instance, young people use new media especially social platform to play games, communicate and chat with others, as well as learning information or new knowledge from the internet (Baboo, Pandian \& Prasad, 2013.

Nowadays, everybody uses social media such as Facebook, YouTube and Twitter in their life from communicating, promote, gain supporter and generate income. India was one of the top 20 countries with the high number Internet user. By 31 December 2017, India was the second highest user with a number of a user is around 462 million (Internet World Stat). According to Statista, Internet users in India is estimated to increase to 635.8 million by 2021 compared to previous years (Statista). So, social media nowadays became popular as major tools to the politician in India to interact with people and practically play news roles in Indian democracy. More politician used social media as a tool in their political campaign and opened new medium in the political arena.

In 2008, the first mass used of social media happens when Mumbai Attack happens, which is Indian and the outside share information through a medium like Twitter. Meanwhile, second mass use of social media started when politician and parties try to attract voter using social media in May 2009 National Election. For example, it's seen that Bharatiya Janata Party (BJP) being a seed to use social media even before the 2009 general election. Another politician, such as Prime Minister of India, Narendra Modi and Presiden of Indian National Congress, Rahul Gandhi also used social media to communicate with people. (R. Prakash Sings, 2016). Member of Parliament (MP) Lok Shaba, Shashi Tharoor was first one among Indian politician start tweeting, frequently mentioned as the Twitter Minister (Rajput, 2014).

According to Katkar (2014) and Kaur and Verma (2016), Delhi General Election 2014 showed that all political parties effectively use social media to engage with people, mainly voter and pursues votes. However, social media also being used by a politician or political parties to be mocking each other, as it did by BJP by calling Rahul Gandhi as Pappudan Narinder Modi being called as Feku by India National Congress (Kaur \& Kaur, 2013).

Muntean (2015) stated that social media is a worthwhile medium in the political realm today for a politician to win over and reach out voter. Moreover, a voter also can know election candidate or politician better before choose using social media. But, did new media play important roles and give advantage for a politician in India to attract people especially the young generation that less involved in politics, like do voting in the election.

\section{Research Objectives}

This research has the following objectives:

a. To study the impact of new media on politic in India on the upcoming general election.

b. To analyse the ability of new media to changed political scenario in India.

c. To examine the used of new media in a political campaign by Indian politician from editor perspectives. 


\section{Research Questions}

This research has the following questions:

a. What is the impact of new media on politic in India on the upcoming general election?

b. Are new media having the ability to change the politic scenario in India?

c. How new media can influence political campaign by Indian politician from editor perspective?

\section{Scope of Research}

This research will involve media organization staff such as the editor of a foreign desk in the media organization.

\section{Significant of Study}

The study is focusing on the roles in new media on politic in India. The use of social media, such as Twitter and Facebook among candidate and political parties itself will able to give impact on their campaign. This year, India General Election expected to be held between April to May 2019. Social media will be a major battleground for political parties, such as BJP, India National Congress and AAP for this upcoming election.

\section{Problem Statement}

New media with is low cost became a new force and emerging tool for political communication, engagement, and participation. But India also applies censorship and restriction about issues of political and social conflict since 2003. For instance, India argument with Pakistan over Kashmir or other cases, like an issue between castes.

With the growing demand of the internet in India that include 29 states and seven union territories, network disturbance became one of the major worries in the country. Moreover, network problem ever happened during the political conflict in Jammu and Kashmir in January 2012. Furthermore, based on a survey in 2018, 43,088 villages of 5.9 million villages in India still don't have mobile phone service.

So, the platform effective to influence people stills a question. Yet, many politicians begin to use social media in their campaign to approach people in the previous election, such as Delhi General Election 2014 intriguing the attention of researchers. This paper explores how India politician using new media as a campaign platform to reach out voter.

\section{Literature Review}

The purpose of this section is to provide an overview of the current research about the roles of new media on politic. Firstly, a brief description of the Indian Election in 2014, followed by a discussion about the type, roles and influence social media in the political arena.

\section{The Type of New Media}

Putri, Prananingrum and Safirti (2018) tell that new media can be described as the growth digital, computer or network information technology and communication. This platform consist blog, podcast (Nicoleta, 2008), Facebook, YouTube and many more (Friedman \& Friedman, 2008).

Meanwhile, according to Manning (2014), as part of new media then social media is the term often used to define the new forms of media that consist of interactive involvement. Example: 


\section{Facebook}

What is Facebook? According to Feye, Couck, Stough, Vigna and Bois (2013), Facebook is the worldwide platform that became one important social trend to the public in the past decade. User can create an account by delivering their personal information like the name through Facebook. With this platform, the user can share anything on their status before their friend responds by comment. The goal of this paper is to study the topological characteristics of Twitter and its power as a new medium of information sharing.

\section{Twitter}

Kwak, Lee, Park and Moon (2016) say that Twitter is a microblogging service that allows a user to write any topic in 140 characters only. Twitter user can follow others to receive their messages that also being called as tweets but doesn't require others to follow back. There few things used in Twitter such as RT (retweet) or \# (hashtag).

\section{YouTube}

YouTube is referring to a video sharing website that allows a user to upload, share and watch the video for free. YouTube is one of the most popular social media that include content like movies and music video. This social media favoured by people because it provides the latest video to them. Furthermore, some people also use this medium to show creativity and channelling their talent (Setiawan, 2013).

\section{New Media Characteristics}

Setiawan (2013) stated that new media have several characteristics that can be identified including:

- Easy to access

User can access the internet through gadget like the computer, laptop and smartphone to get information, watch video, promotion and marketing product anytime or anywhere.

- Have network

User can interact with the whole world without concern to the national border as long as it has network by doing connection to an internet service provider (ISP)

- Interactive

Tools that are designed with the use of computers using elements such as sound (audio), images (visual) and text to deliver a message.

Meanwhile, Pradepp (2014) adds that another characteristic of new media besides interactive is:

- Immediacy

People can share all information from the entire world quickly with $3 \mathrm{G}$ and $4 \mathrm{G}$ technology.

- Universality

Story of current incident happens anywhere is reachable to any other level within in short term without limitation by space or time.

- Hypertext

Hypertext refers to text which offers a network of links to other texts that are 'outside, above, and beyond' themselves.

- Multimedia

Refer to the news that being supported by cartoons, sound, and music. Information, graphic, sound, and data can transfer and exchange through multimedia systems. 


\section{The Used of New Media During the Election}

In Indian General Election 2014, BJP and Aam Aadmi Party (AAP) use widely social media, for example, Twitter to associate and engage with a supporter during the campaign. Both political parties also shared campaign-related materials such as videos and memes in social media. As a result, the BJP social media campaign became one of its causes winning the election (Chadha \& Guha, 2016). The election stood as most prolific and historic elections in the whole democratic history of India. Respective parties use various social media like Twitter to create awareness about candidate profile, manifesto up to procedure of voting. In fact, it also uses as marketing parties, poll prediction, and analysis about the election (Shushi).

Safiullah, Pramod Pathak and Anshul (2016) mentioned social media as an emerging tool being used widely to converse with the voter in the politic arena. They are a different type of social media can be used, such as Facebook and LinkedIn (social networking), Twitter (microblogging) and YouTube (media sharing). For example, Twitter can be a very suitable platform to share the political campaign with target voter for political parties as it's happening in various countries.

These days, social media gradually popular especially among young generation because it provides benefit, such as communicate, share information and interact with each other without limitation. Moreover, social media growth as a device for political parties and politician to reach people in a short time. Unlike traditional media, this platform also let candidate doing many things with a voter, including engaging directly with them (Narasimhamurthy, 2014).

Kulkarni (2017) suggests that political campaigners use meme as part of a political campaign and platform to communicate with netizen in social media. Moreover, the number of social media user used the medium to share material or giving comment for political activities became growing, thus boosts political engagement.

\section{Media Theory}

Bennet (1982) stated that Theories of Media and Communication was noteworthy as its existence in this world backing media people achieve their dream such as to determination the certain problem that causes. In this research, the theory will support to find out whichever media give information, provide influence, create a problem or so on toward society. Thus, Agenda Setting Theory will be use to support the research.

McCombs and Shaw (1972) introduced the theory in 1972 based on the 1968 Presidential Election in North Carolina. Them found that there was a connection amid what voters believed was vital and the issue of media attention through the study. The theory is seen to verify that the media can influence the public on the meaning of an issue. Thus, it can be said that media attention on any issue will be more or less known by the public, while less media attention on any issue will be less known by the public. In additional research, McCombs and Shaw (1977), think that this theory related to issues such as news event or news issues that being offered by media to study audience mind about a certain issue. This statement also support by (Purvis, 2001) that think media can manipulate audience mind using Agenda Setting Theory. This revealed that can media give influence by change audience opinion and choice. Meanwhile, Rogers \& Dearing (1988) says that Agenda Setting Theory consist media, public, and policy agendas. In their further studies, Rogers and Dearing (1992) claimed that the media agenda is a media-driven issue, the public agenda discusses to issues considered important to the public and the policymakers' agenda is one that symbolizes a country's policymakers. Academician Akpabio (2005) believed that media organization have certain agenda toward society by a 
distributed news article in the newspaper often. Agenda setting theory uses to accomplish something such as to give publicity.

There are few local and international academians using Agenda Setting Theory in their research. For example, research on 'Twittering public sentiments: A predictive analysis of prepoll Twitter popularity of Prime Ministerial candidates for the Indian Election' that adopt a volume, engagement and sentiment analysis for predicting the popularity of Prime Ministerial candidate on Twitter as a run-up to the India Election 2014 proved the agenda setting influence of Twitter toward candidate (Suresh \& Ramkrishnan, 2015). In Chanda \& Bose research 'Social media and agenda-setting:A study of the changing trends of electon campaign in India' showed that the changing trend of campaign when Bharatiya Janata Party (BJP) and its candidate Narenda Modi popular due to social media campaign. In the study, researcher try to find out how media sets the agenda for election and induces popular emotion and sentimens between public. Meanwhile, Baumann, Zheng and McCombs (2017) studied on 'First and second-level agenda-setting in the 2014 Indian general election: a time-series analysis of partymedia relation' proved that media coverage focus on candidate from Bharatiya Janata Party (BJP)'s Narendra Modi. This recount to study by McCombs and Shaw (1972) that the frequency of coverage can lead to increase attention toward related issues.

There is a study by Ali and Ajaz (2014) on 'Social media and Indo-Pak Relations:Applying Agenda Setting Theory' it set another example connectin between social media and Agenda Setting Theory when finding showed that the Indo-Pak tension and its thoughts and responses on social media are the true examples of negative agenda setting. Meanwhile, Caulk (2016) examine about agenda-setting in the media, and how it contributed to the Trumpish spread in study 'Trumpism: How agenda setting in the media drove a movement'. This study find out that news coverage signals the public that Trump was the most important candidate from the Republican Party during the 2016 Presidential.Besides that, there are also the study about 'Media Agenda and Public Agenda: A Study of Issues during the 13th General Election' by researcher Manaf, Taibi and Manan (2017). The academician observe issues of attention of the mainstream media of Malaysia, as well as issues of public attention during the 13th General Elections in this research. Meanwhile, Shafie, Karim, \& Salleh (2018) exploring study about 'Hubungan agenda media dan Faktor keselarian Politik'. The article focuses on the Agenda Setting Theory and Permatang Pauh By-Election 2015 to identifying the media agenda between Utusan Malaysia newspaper and Free Malaysia Today news portal, and analyzing the patterns of news coverage of different media by owning aspects of news themes and leaning on the news. In addition, Shaik (2009) investigate main themes of the issue, examine the flow of the issue and the online news coverage of the news coverage presented on the two websites during the 2004 General Election Campaign in research about 'Pembinaan Agenda Media dalam laman web Malaysiakini dan Agendadaily semasa tempoh Pilihan Raya Umum 2004. Those study prove the statement by

In this study, Agenda Setting Theory was selected as a theory in the media that is fits to study. This theory is important in the study as the existence of various traditional and new media include India. Some media allegedly belong to a particular political party. So, this study lets us know if the media is leaning towards the party under its ownership.

\section{Methodology}

This section discusses the item related to this research such as research method that related roles of new media on politic in India. Idid (1993) says that once there are problems then the data searchable via methodologies. Meanwhile, according to Baharom (1998), the 
methodology uses to solve the research. Which is research is the method to check or investigate. Using research methods, overall methods taken to achieve all the objectives of the research.

Although part of the research process can be done in the library, the greatest approach to make research is going down to the field. Thus, the scholar would look and study actual events that occur in social life. Therefore, the significant research actually based on the data resulting from field work such as interview (Idid, 1993).

In order to fulfil the research objectives, a qualitative technique was conducted. The qualitative research method uses an in-depth interview. This method is subjective because the individual interpretation of events is important.

Maxwell (2005) says that the qualitative method is one method of research design that the reflexive process that operates with a various stage.

In this research, the in-depth interview involved converse with various media organization staff, such as the editor of the foreign desk regarding the roles of social media on politic in India. In this study, five foreign desk editors from a different organization that have more than 10 years in the media industry being an interview about 30 minutes to one hour.

Furthermore, this study also used method includes the collection of secondary data (information that is available) that are closely related studies, especially those involving reference to support researcher study about reader perception regarding on topics of study. This information is usually obtained from libraries, archives and more but not from major information resources, such as a book (print media) or Internet (electronic media) (Hashim, n.d.).

\section{Data Analysis and Findings}

According to Braun and Clarke (2012), a thematic analysis is an open and common method of qualitative data analysis used to finding, organizing and offering to understand through the interview-based study of roles of new media on politic in India. There are three main themes found based on the thematic analysis about the use of new media (Braun \& Clarke, 2012) that is done in this research, which are: 1) accessibility, 2) political participant and 3) Editor perspective.

\section{Accessibility}

The increase of speed internet access and smartphone make new media, like Facebook, Twitter, WhatsApp, YouTube, Instagram, and LinkedIn well received by all age group in India, especially among the young generation (Bhardwaj, Avasthi, \& Goundar, 2017).

Informant 1 and 2 noted that public use various new media platform to participate in political discourse in order to get updated information.

"Indian people who receive internet access using Facebook, Twitter, and WhatApps to get the latest information no matter when in politics. It can be said, social networking users, such as Twitter and Facebook in India are quite high."

"Among the new media used in India are Twitter, Facebook, and WhatsApp. The number of users is huge. So, they only use the platform to get information on current and political issues." (I2) 
But, Prabu and Manoov (2013) inform that rural area in India has a lower level of internet access or not even have internet connectivity compared to other regions because of many factors, such as poor infrastructure.

According to informant 1, not everybody uses the internet and social media because not all area in India internet access, so the public used other media to get information. Informant 2 adds that internet connectivity problem experienced by people rural and conflict.

"There are over 600,000 villages in India, however not all areas get electricity supply, not to mention an internet. In fact, it can be said that over 40,000 villages still have no cellphone service. So, still many areas don't have the technology yet. So, most people get information on television." (I1)

"However, rural and turbulent areas have to rely on television for information because difficult to get internet access. In fact, people from with no technological facilities area will be waiting for locals to come home with news and stories about the latest developments in the community hear by them." (I2)

Informant 1 thinks that there is a huge gap between the rural and urban to access political information via the internet and a social medium, which is also agreed by informant 2 .

"Indeed, there is a huge gap for urban and rural people to get information through new media. In urban areas, there is no problem finding any information, as long as it has internet access. "

"For rural areas or raging areas, there is still no access to internet facilities due to lack of facilities, distances location, and restrictions." (I1)

"Only by using the internet and social media urban people already can get information on politics. Many people can use the facility as a result; mobile internet services are cheaper in India."

"However, most people living in rural areas are struggling to find the latest information on the internet. This is because of lack of internet access, poor line problem, poverty and the inability to purchase smartphones." (R2)

Besides that, informant 1 claims that accessibility in the internet and social media to get political information in India also influence by restriction and censorship. Informant 2 backing up the statement by stated that the government will restrict social media if it can threaten security and affects the country.

"India is among the world's most frequent country that block and closes its internet access. Most internet restrictions involve issues of religion, caste, conflict, violence, politics, government and offensive. Previously, India once closed and banned more than 20 social sites including Twitter, Facebook, and WhatApps in Kashmir." (I1)

"Because of a lot of false information is spreading that has a negative effect, which led to attacks and killings, then the application was blocked. Last year, a young man was attacked by rumours in WhatsApp that the man was kidnapped. The men were injured, and his friend was killed." 
"The Indian government has imposed restrictions on social media such as Facebook and Twitter for allegedly being able to cause riots when abused by anti-government elements to create rebellious violence in Kashmir." (I2)

\section{Political Participants}

According to Singh (2016) and Rajput (2014), Prime Minister of India, Narendra Modi, Presiden of Indian National Congress, Rahul Gandhi and Member of Parliament (MP) Lok Shaba, Shashi Tharoor was among politician in India used new media.

Most of the politicians and parties began to master and used new media completely in an election campaign, besides go on the field. Prime Minister of India, Narendra Modi has proven that good internet and social media usage is able to influence victory in an election when he wins di India General Election in 2014. Today, many other politicians take the same step.

"In India, some politicians are also using the new media as best they can, including Narendra Modi of Partai Bharatiya Janata (BHP) who have many followers in social media. He is now Prime Minister of India after winning the 2014 Indian General Election." (I1)

"As far as I know, many Indian politicians use this internet, such as Narendra Modi, Rahul Gandhi, Shahshi Taroor, Arvind Kejriwal, Suresh Prahbu and Smritilrani because they know the advantages of using the platform." (I2)

All political parties in India successfully use social media to engage with people, mainly voter and tracks votes in 2014 India General Election (Katkar, 2014; Kaur \& Verma, 2016).

Informant 1 and 2 agreed that they used various types of new media from Twitter to Facebook to WhatsApp for their political interest, such as approach voter.

"Modi uses various technology tools from Google Hangout to social media. He is among the well-known politicians on Twitter after Barack Obama. Modi used various new media to get a general view during his campaign. In fact, he uses social media to reach out to the public, especially potential voters by communicating with them. He is also seen telling their political vision in social media, which is seen as being able to attract public attention." (I1)

"Politicians or political parties are using the new media platform to connect with the people, especially the younger generation on their agenda and political activities. We see through India General Elections in 2014, when social media is a place to battle various political campaigns and political views." (I2)

Informant 1 suggests that use of new media effectively enhances the potential win the heart of people, at once won in the election, but likely to lose if it fails to use the platform properly. His views are supported by informant 2 that add that lack of used social media may result in failure to dismiss the slander of fake news against themselves.

"Modi himself won because he was wise to use social media regardless of Twitter or Facebook is the proof. At the same time, we can see that the lack of social media use can affect politicians to lose in elections because of the lack of popularity among voters especially young people." (I1)

"If any politician fails to deny slander and fake news the social media, they are likely to lose the election. Thus, they and their parties need to be more 
aggressive in social media to gain the trust of the people, as well as rid the slander." (I2)

Furthermore, informant 1 and 2 admit that public rage in new media towards political struggle slight maybe affect the decision of the government.

"From my view, the public rage is not whether the internet or on the street may influence government decisions a little bit. However, it must first be approved by the Indian Cabinet."

"Murkherjee signed an Anti-Corruption Law that imposed severe penalties on offenders including the death penalty due to mass protests of Indian citizens with street protests and social media." (I1)

"Beside street protest, Indian people rage in social media in the issue of rape put pressure on the government to make the right decision."

"For example, we see rape cases that take place near India, which is protests are spread out from India to the rest of the world. Through Facebook, a user signs a petition condemning the attack and urging the death penalty to the perpetrator. In this case, the Indian government is facing strong pressure through strong public voices."(I2)

Informant 1 and 2 acknowledge that political mobilization through the internet is increasing got a place in society, at the same time effect to the politics in India.

"The internet can play an important role in politics and give politicians the opportunity to reach out to voters and influence them. So, more and more politicians and their parties are using the new media as their medium."

"Most notably, Prime Minister of India, Narendra Modi and his party, BJP who used social media even before the 2014 India General Election. As we all know, the used social media wisely has led Modi to win in the election." (I1)

"For politicians, the use of the internet is seen as capable of influencing voters' especially young people, as well as triggering many Indian politicians to have social media accounts. As I mentioned earlier, undeniably many politicians use social media, especially the Prime Minister of India, Narendra Modi himself."

"The existence of the internet transforms India's political landscape, which makes all politicians unable to avoid and need to learned social media to attract voters." (I2)

Both informants approve that new media play an important role in politic but it also has a negative effect, especially when used to spread false news.

"There are various issues spread across the internet, however not all are accurate and just mors. However, it can negatively affect the public including any politician involved." "In December last year, a viral message showed that Rahul Gandhi converted to Islam after the Indian National Congress Party won in three states using old video at the mosque before being confirmed fake but still damaged its image." (I1) 
"In fact, the image of Gandhi two years ago being modified shown he was sitting next to a suicide bomber who was involved in an attack on a suicide bomb attack in Pulwama recently." (I2)

\section{Editors' Perspective}

According to Alejandro (2010), the journalism world change with the arrival of social media when it became important as communication and a new breaking tool. Informant 1 emphasizes that new media help make journalist work easier especially get information, but they should not rely solely on the information on new media only, but also other sources. Informant 2 also think internet assistance journalist, but it also makes them became lazier because can copy another people story.

"Even though new media eases our work particularly in terms of obtaining information, but as a journalist, we must adhere to the principles and ethics of journalism when reporting the news."

"To be more precise, we have to read more reading material including book and can refer to overseas media agencies to get more accurate information. Like me, I also have a group of WhatsApp and a good relationship with the embassy of a particular country, so I can get information also through that social app." (I1)

"Personally, I feel that the new media will influence the knowledge of journalists and attitudes but not political interests."

"However, the new media can change journalist attitude. We can be lazy to go down to the field to get the news, then just copy and paste the other written info just like numerous happening in online portals and blogs." (I2)

Nevertheless, both informants agree that new media can't influence political interest among editor by holding ethic and principle of journalism.

"The most important thing is, to report the truth alone and to avoid racial news. So, we will occasionally not allow the presence of new media to influence us by adhering to the journalist ethics." (I1)

"Politicians either from government or opposition parties will use new media to deliver their political agenda, but we should not be influenced to support otherwise neutral. So, social media will not affect political interests as we have been educated to report honest news without being influenced by any party." (I2)

In addition, informant 1 explained that there is a relationship between social media usage and political engagement toward journalist but in another way and not directly, which is politician status in social media can be a news source. Informant 2 has the same opinion.

"These days, politicians love to upload their views on Facebook and Twitter, such as Narendra Modi. Sometimes he raises an issue or answers the question raised by a local on social media. So, we have to be alert and monitor their uploaded status frequently because the statement can be a new source of news." (I1)

"Now, journalists can use the statement to make news from Modi's statement on Facebook. However, we need to make sure that it is the official account of 
Modi. If it is really his owned social media, we can use to make a news report."

(I2)

\section{Discussion}

This research aims to determine the effectiveness of new media on politic in India. The roles of new media toward user can be found through this research. In this study, researchers will use the following methods such as qualitative. The qualitative allows researchers to obtain detail to help to describe the roles of new media by conducting an interview with respondents. In this study, the researcher selected the respondents from media organization especially senior editor and foreign editor. Often the interviews are conduct done weeks, month or year depending on the respondent.

This finding revealed that respondents give their opinion on usability, role and the effectiveness of new media in influencing the public decision in an election in India. The findings showed that the respondent considers new media was a vital tool and play important roles for a politician and political parties, particularly during the election. Narendra Modi from Bharatiya Janata Party (BJP) appointed as Prime Minister of India after win in 2014 Indian General Election. Modi is said to used social media, such as Facebook and Twitter since 2009, which is it led to Modi historic political won. Social media help Modi in the political campaign during an election to reach out public, express vision and agenda, communicate with public and influence voter. Today, Modi is among standout and popular politician in social media in India became an example to others. This was fully demonstrated by Singh (2016) in their study.

Generally, all respondent being interview acknowledge that new media has a great impact on politic in India if being used effectively. But respondent reminds that this platform can affect image and status politician if being misuse by irresponsible people for their interest. Moreover, social media can be used by some people to attack the politician when not satisfied with their statement. The fake news being spread out in new media can make the public lost trust in a politician, even though the information may be false. Academian Bhaskaran, Mishra, \& Nair, (2017) proved that fake news is not new phenomena in India, and they believe in an urban story in their study.

Moreover, findings also show that there is a big gap between urban and rural area on just how people obtain information. Both respondents say that many people in India use new media to gain info nowadays, but clearly, not everybody uses the platform due to factor such as area, poverty, inability to purchase, network problem and so on. Respondent admits people in a rural area was difficult to use social media in order to search info because of internet access and connectivity problem. This finding supports the study by Prabu and Manoov (2013) on 'Analysing the Impact of the Internet in Rural India'. In addition, respondent thinks internet restrictions, especially in a conflict area like Kashmir, make accessibility harder.

Hence, these finding also discover new media help and ease journalist work in obtaining material and reporting news from editor perspective. All respondent has the same opinion that new media can be a new news source, but can't depend too much on that platform itself, instead of other reading material as well. They also agree that new media can't influence political interest if they are holding ethic and principle of journalism. These findings notice politician engagements in social media usage can be news source to the journalist. These findings were demonstrated by Paulussen, Harder and Johnson (2017) in their research. 


\section{Conclusion}

The emergence of new media plays an important role in the political campaign and to build a good image. In order to do so, the problem such as network, internet access and poverty must be handled. Social media and internet freedom is required but on term and condition be compiled in order to avoid abuse of the platform. Hence, a view from social media and internet user including politician, voter, and journalist is significant to make sure that social media being used wisely. It is undeniable, a politician who is able to use social media and the internet well is more influential to people. This research on the roles of new media on politic in India was a pilot study. In conclusion, to find out the effectiveness of new media in the political campaign needs additional and further study.

\section{Limitation of Study}

In this research, there is five foreign editors being an interview to get feedback based on the experience in the media industry. But, during the course of the study, researchers have faced some problems. The main problem is some respondent doesn't have any knowledge of foreign countries despite working at a foreign desk. This is because they never sending or assigned to cover overseas. Thus, it makes their knowledge about a country quite limited. There are respondents who have the opportunity to cover in certain countries, but they only know about the country being visited only. However, the respondent informed that they always read to add their knowledge about any country in the world.

Moreover, conducting an interview with every media organization in Malaysia located around Kuala Lumpur and Selangor is difficult due to the distance of each company from each other and running out of time. So, the researcher had to divide and set the appropriate time to conduct the interview with the respondent. Besides that, not all media organization give respond to for the interview session. This is maybe because they busy with the assignment and can't spend time on the session. However, researchers pursue to gain information in any way to improve the facts in this study. References to secondary materials greatly help researchers in preparing this study.

\section{Recommendation}

Although the research results finding found that most respondent support that social media can influence people including on politic in India, but network problem and internet restriction in India still needs to change in order to attract people. They are various opinion can be used to improve the change such as:

\section{Used Various New Media}

A politician needs to use new media as best as they can. They should not use only one, but more social media from Facebook, Twitter to YouTube and so on is much better to gain follower and attract people.

\section{Introduce $5 G$}

The emergence of $5 \mathrm{G}$ technology will help to provide an opportunity for all people to get highspeed internet after the appearance $2 \mathrm{G}$ (give user voice calling and text messaging), $3 \mathrm{G}$ (paving the way for internet on a mobile phone, enabling picture-sharing and Bluetooth) and $4 \mathrm{G}$ (innovation the apps and content).

\section{Provide Broadband to Every Village in India}

Network problem in some remote and rural area in India will be handled when this plan is implemented. 


\section{Open Up the Blocking Internet Service with Condition Adhere to The Guideline}

In order to give information that up to date from to time and accurately without control, so India must open up blocking the internet. For the record, India among the countries that have the world's largest internet restriction which gives a certain impact to society.

\section{References}

Akpabio, E. (2005). Toward a Public Relations' Agenda Setting Theory. Department of Mass Communication, University of Lagos, Lagos, Nigeria. Retrieved from http://www.krepublishers.com/02-Journals/JSS/JSS-11-0-000-000-2005-Web/JSS-113-173-258-2005-Abst-PDF/JSS-11-3-173-176-2005-232-Akpabio-E/JSS-11-3-173176-2005-232-Akpabio-E-Full-Text.pdf

Alejandro, J. (2010). Journalism in the Age of Social Media. Retrieved from https://www.google.com/url?sa=t\&source=web\&rct=j\&url=https://www.mediaforum. $\mathrm{md} /$ upload/theme-files/journalism-in-the-age-of-social-mediapdf 554fbf10114c6.pdf\&ved=2ahUKEwiX29aPmbThAhVDuo8KHfaJAC8QFjAEegQIB hAB\&usg=AOvVaw3d6giL6Gj_iGwgOCHOk9mn

Ali, Z., \& Ajaz, N. (2014). Social media and Indo-Pak Relations: Applying Agenda Setting Theory. Retrieved from https://www.academia.edu/8996988/Social_Media_and_IndoPak_Relations_Applying_Agenda_Setting_Theory

Baboo, D. S., Pandian, D. A., \& Prasad, A. R. (2013). Young people and new media in Malaysia: An Analysis of social uses and practices. Retrieved from https://www.google.com/url?sa=t\&source=web\&rct=j\&url=http://www.researchersw orld.com/vol4/issue2/Paper_07.pdf\&ved=2ahUKEwjS-r

fiI31AhWSinAKHeMmAWEQFjAAegQIARAB\&usg=AOvVaw0WrVSsQ3wnNu7M FGJWgCfq

Baharom, H. N. (1998). Kamus Dewan Edisi Ketiga. Kuala Lumpur: Dewan Bahasa dan Pustaka.

Baumann, H.-C., Zheng, P., \& McCombs, M. (2017). First and second-level agenda-setting in the 2014 Indian general election: a time-series analysis of party-media relation. Retrieved

from https://www.tandfonline.com/doi/full/10.1080/01292986.2017.1390773?scroll=top\&n eedAccess $=$ true

Bennet, T. (1982). Theories of the Media, Theories of Society. Retrieved from http://web.mit.edu/211.432/www/readings/Bennett_TheoriesOfMediaAndSociety.pdf

Bhardwaj, A., Avasthi, V., \& Goundar, S. (2017). Impact of social networking on Indian YouthA Survey. Retrieved from https://www.researchgate.net/publication/322538324_Impact_of_Social_Networking_ on_Indian_Youth-A_Survey

Bhaskaran, H., Mishra, H., \& Nair, P. (2017). Contextualizing Fake News in Post-truth Era: Journalism Education in India. Retrieved from https://www.google.com/url?sa=t\&source=web\&rct=j\&url=http://journals.sagepub.co m/doi/pdf/10.1177/1326365X17702277\&ved=2ahUKEwjUmqLqxrThAhXWX30KH fosAOAQFjAEegQIAxAB\&usg=AOvVaw0I8cH-dLeOhJljZ3Hk5Ols

Braun, V., \& Clarke, V. (2012). Thematic Analysis. Retrived from https://www.researchgate.net/profile/Victoria_Clarke2/publication/269930410_Them atic_analysis/links/5499ad060cf22a83139626ed 
Caulk, A. J. (2016). Trumpism: How agenda setting in the media drove a movement. Retrieved from https://www.mobt3ath.com/uplode/book/book-46511.pdf

Chadha, K., \& Guha, P. (2016). The Bharatiya Janata Party's Online Campaign and Citizen Involvement in India's 2014 Election. Retrieved from https://ijoc.org/index.php/ijoc/article/download/4947/1774

Chanda, D., \& Bose, S. (n.d.). Social Media and Agenda-Setting:A study of changing trends of election campaigns in India. Retrieved from https://www.academia.edu/31055869/Social_Media_and_Agenda-

Setting_A_Study_of_the_changing_trends_of_election_campaigns_in_India

Feye, R. C., Couck, M. D., Stough, T., Vigna, C., \& Bois, C. D. (2013). Facebook: A Literature Review.

Retrived

from https://www.researchgate.net/publication/258173969_Facebook_A_literature_review

Friedman, L. W., \& H.Friedman, H. (n.d.). The New Media Technologies: Overview and Research Framework. 2008. Retrieved from https://www.researchgate.net/publication/228193979_The_New_Media_Technologies _Overview_and_Research_Framework

Hashim, R. (n.d.). Panduan Menulis Kertas projek dan Latihan Ilmiah. Jabatan Komunikasi Fakulti Sains Kemasyarakatan dan Kemanusiaan Universiti Kebangsaan Malaysia.

Idid, S. A. (1993). Kaedah Penyelidikan Komunikasi dan Sains Sosial. Dewan Bahasa dan Pustaka.

Katkar, A. S. (2014). Impact of social media on Indian Politics. Retrieved from http://www.academia.edu/6912798/Impact_of_Social_Media_on_Indian_Politics_Im pact_of_Social_Media_on_Indian_Politics

Kaur, M., \& Verma, R. (2016). Social Media: An Emerging Tool for Political Participation. Retrieved

from https://www.researchgate.net/publication/304536968_Social_Media_An_Emerging_T ool_for_Political_Participation

Kaur, S., \& Kaur, M. (2013). Impact of social media on politics. Retrieved from https://www.gjimt.ac.in/wp-content/uploads/2017/10/3_Surjit-Kaur_Manpreet-

Kaur_Impact_of_social_Media_on_Politics.pdf

Kulkarni, D. A. (2017). Internet meme and Political Discourse: A study on the impact of internet meme as a tool in communicating political satire. Retrieved from http://www.amity.edu/gwalior/JCCC/pdf/JCC-Journal-December-2017-13-17.pdf

Kwak, H., Lee, C., Park, H., \& Moon, S. (2016). What is Twitter, a Social Network or a News Media.

Retrieved

from http://www.ambuehler.ethz.ch/CDstore/www2010/www/p591.pdf

Kaplan, A., \& Haenlein, M. (2010). Users of the world, unite! The challenges and opportunities of social media". Retrieved fromhttp://michaelhaenlein.eu/Publications/Kaplan,\%20Andreas\%20$\%$ 20Users\%20of\%20the\%20world,\%20unite.pdf

Manaf, A. M., Taibi, M., \& Manan, K. A. (2017). Media Agenda and Public Agenda: A Study of Issues during the 13th General Election. Retrieved from http://journalarticle.ukm.my/10564/1/19085-54087-2-PB.pdf

Manning, J. (2014). Definition and Classes of Social Media. Retrieved from https://www.researchgate.net/publication/290514612_Definition_and_Classes_of_Soc ial_Media

Maxwell, J. A. (2005). Qualitative research Design: An Interactive Approach. U.S.A.: Sage Publications LTD. 
McCombs, M. E., \& Shaw, D. L. (1972). The Agenda-Setting Function of Mass Media.). Retrieved from https://www.researchgate.net/publication/209410047_The_AgendaSetting_Function_of_Mass_Media/link/5526c09f0cf2e486ae40c0d2/download

McCombs, M. E., \& Shaw, D. L. (1977). The Emergence of American Political Issues. New York: West Publishing Co.

Muntean, A. (2015). The Impact of Social Media Use of Political Participation. Retrieved from http://pure.au.dk/portal/files/90378581/The_Impact_of_Social_Media_on_Political_P articipation.pdf

Narasimhamurthy, N. (2014). Use and Rise of Social media as Election Campaign medium in India. Retrieved from http://www.ijims.com/uploads/7f33858cd2c22045d277A27.pdf

Nicoleta, C. (2008). The Impact of New Media on Society. Retrieved from https://www.researchgate.net/publication/215489586_The_impact_of_new_media_on _society

Paulussen, S., Harder, R. A., \& Johnson, M. (2017). Facebook and news journalism. Retrieved from ohttps://www.researchgate.net/publication/311948076_Facebook_and_News_ Journalism/download

Prabu, \& Manoov. (2013). Analyzing the Impact of Internet in Rural India. Retrieved from https://www.researchgate.net/publication/264159967_Analyzing_the_Impact_of_Inter net_in_Rural_India

Pradepp, D. L. (2014). Introduction to New Media. Retrieved from http://www.universityofcalicut.info/cuonline/exnotif/ex4460.pdf

Purvis, H. (2001). Media, Politics and Government. USA. University of Arkansas: Harcourt College Publishers.

Putri, K. Y., Prananingrum, E. N., \& Safirti, D. (2018). Literasi Media Baru dan Budaya Baru di Masyarakat Indonesia. Retrieved from https://www.researchgate.net/publication/326913529_LITERASI_MEDIA_BARU_D AN_BUDAYA_BARU_DI_MASYARAKAT_INDONESIA

Rajput, H. (2014). Social Media and Politics in India: A Study on Twitter Usage among Indian Political Leaders. Retrieved from http://www.academia.edu/5925046/Social_Media_and_Politics_in_India_A_Study_o n_Twitter_Usage_among_Indian_Political_Leaders

Rogers, E. M., \& Dearing, J. W. (1988). Agenda-Setting Research: Where Has It Been, Where Is It Going? Retrieved from https://www.researchgate.net/profile/James_Dearing2/publication/263809220_Agend a-

Setting_Research_Where_Has_It_Been_Where_Is_It_Going/links/57e57ee308ae9e5e 45501564.pdf

Rogers, E. M., \& Dearing, J.W. (1992). Thousand Oaks, CA: Sage.

Safiullah, M., Pramod Pathak, S. S., \& Anshul, A. (2016). Social Media in managing political Advertising: A study of India. Retrieved from http://yadda.icm.edu.pl/yadda/element/bwmeta1.element.baztech-5cefd290-61c14cc0-aa80-cccbfe0a874a/c/Safiullah_PJMS_13_2_121.pdf

Setiawan, R. (2013). Kekuatan new media dalam membentuk budaya populer di Indonesia (Studi tentang menjadi artis dadakan dalam mengungah video musik di Youtube). Retrieved from https://ejournal.ilkom.fisip-unmul.ac.id/site/wpcontent/uploads/2013/06/Junal\%20Rudi\%20Ganji1\%20(06-01-13-04-50-33).pdf

Shafie, N. Z., Karim, H. A., \& Salleh, N. (2018). Hubungan agenda media dan faktor keselarian politik. Jurnal Komunikasi Borneo 2018 Vol. 6 (Edisi Khas Konvokesyen UMS ke-20) Disember 2018. Retrieved from https://jurcon.ums.edu.my/ojums/index.php/jkob/article/view/1573/992 
Shaik, A. R. (2009). Pembinaan Agenda Media Dalam Laman Web Malaysia Kini dan Agenda Daily Semasa Tempoh Kempen Pilihan Raya Umum 2004. Retrieved from http://psasir.upm.edu.my/id/eprint/5772/1/AK_FBMK_2009_11.pdf

Shushi, P. (n.d.). A Case study on Use of Social Media in Indian General Election-2014. Retrieved from https://www.academia.edu/7676021/Case_Study_on_Use_of_Social_Media_in_Gene ral_Election_India_2014

Singh, D. R. (2016). Role of social networking sites in Indian politics. Retrieved from http://www.socialsciencejournal.in/download/95/2-4-28.pdf

Situmorang, J. R. (2012). Pemanfaatan Internet Sebagai New Media Dalam Bidang Politik, Bisnis, Pendidikan Dan Sosial Budaya.Retrieved from https://media.neliti.com/media/publications/73847-ID-pemanfaatan-internet-sebagainew-media-d.pdf

Suresh, K., \& Ramkrishnan, C. (2015). Twittering public sentimens: A predictive analysis of pre-poll Titter popularity of Prime Ministerial candidates for the Indian Elections 2014. Retrieved from https://www.academia.edu/38926787/Twittering_Public_Sentiments_A_Predictive_A nalysis_of_Pre-

Poll_Twitter_Popularity_of_Prime_Ministerial_Candidates_for_the_Indian_Elections _2014 